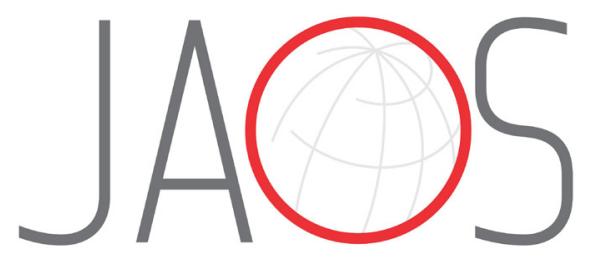
JOURNAL OF APPLIED ORAL SCIENCE

\title{
Perillyl alcohol has antibacterial effects and reduces ROS production in macrophages
}

\section{Abstract}

Rebeca Dantas Alves FIGUEIREDO' ${ }^{1}$ Adriana Cabrera ORTEGA ${ }^{2}$ Laura Andrea

GONZÁLEZ MALDONADO²

Ricardo Dias de CASTRO

Mario Julio ÁVILA-CAMPOS ${ }^{3}$

Carlos ROSSA JUNIOR ${ }^{2}$

Sabrina Garcia de AQUINO
Submitted: September 11, 2019
Natural products have emerged as a rich source of bioactive compounds for adjunctive treatments of many infectious and inflammatory conditions, including periodontitis. Among the monoterpenes with significant biological properties, there is the perillyl alcohol $(\mathrm{POH})$, which can be found in several essential oils and has shown immunomodulatory properties in recent studies, which may be interesting in the treatment of non-neoplastic inflammatory disorders. Objective: To determine the antibacterial and immune modulatory activities of the $\mathrm{POH}$. Methodology: The minimum inhibitory concentration (MIC) and the minimum bactericidal concentration (MBC) of the $\mathrm{POH}$ for two significant Gram-negative periodontal pathogens were determined by macrodilution and subculture, respectively. Cell proliferation and cytotoxicity in RAW 264.7 macrophages were determined by Trypan Blue and mitochondrial enzymatic activity assay. The modulation of reactive oxygen species (ROS) was analyzed by flow cytometry and expression of TNF and arginase- 1 by real-time PCR. Results: The POH was effective against $P$. gingivalis (ATCC 33277) and F. nucleatum (ATCC 25586) with MIC= $\mathrm{MBC}=1600 \mu \mathrm{M}$. No cytotoxicity up to $100 \mu \mathrm{M}$ was observed on macrophages. The cell proliferation was inhibited from 48 hours at $100 \mu \mathrm{M}(\mathrm{p}<0.05)$ and $250 \mu \mathrm{M}(\mathrm{p}<0.01)$. The POH increased ROS production at both $10 \mu \mathrm{M}$ and 100 $\mu \mathrm{M}(\mathrm{p}<0.05)$ in unstimulated cells. The PMA-induced ROS production was not affected by $\mathrm{POH}$, whereas $100 \mu \mathrm{M}$ significantly reduced lipopolysaccharideinduced (LPS-induced) ROS. The expression of TNF was not affected by $\mathrm{POH}$ in unstimulated cells or in cells polarized to M1 phenotype, whereas both concentrations of $\mathrm{POH}$ reduced $(\mathrm{p}<0.05)$ the expression of arginase- 1 in $\mathrm{M} 2-$ polarized macrophages. Conclusion: The $\mathrm{POH}$ has antibacterial activity against periodontal pathogens and reduced proliferation of murine macrophages without significant cytotoxicity at concentrations up to $100 \mu \mathrm{M}$. In addition, the $\mathrm{POH}$ reduced the LPS-induced ROS and the expression of arginase- 1 in M2-polarized macrophages.

Keywords: Periodontal diseases. Immunomodulation. Macrophages. Natural products.

1Universidade Federal da Paraíba, Programa de Pós-Graduação em Odontologia, João Pessoa, Paraíba, Brasil.

2Universidade Estadual Paulista (UNESP), Faculdade de Odontologia de Araraquara, Araraquara, Departamento de Diagnóstico e Cirurgia, São Paulo, Brasil.

${ }^{3}$ Universidade de São Paulo, Instituto de Ciências Biológicas, Departamento de Microbiologia, São Paulo, Brasil. 


\section{Introduction}

In the last decades, advances in periodontal studies have increased the knowledge about the pathogenesis and its immunological mechanisms that modulate the host response to microbial challenge. Thus, although the onset of periodontitis is dependent on the maturation of a complex microbial biofilm (essentially composed of Gram-negative anaerobes), the progression, the extent, and the severity of the disease are dependent on the balance between proinflammatory and protective mediators, which involves complex host-microbial interactions. ${ }^{1}$

In this context, some cell types are particularly significant for tissue homeostasis in the periodontal microenvironment, such as macrophages. The macrophages are highly prevalent in diseased periodontal sites, and as the prototypical antigenpresenting cell, are directly involved in the response to the microbial challenge. ${ }^{2}$ Activated macrophages also secrete important mediators in extracellular matrix degradation and resorption of alveolar bone, and can vary into bone-resorbing osteoclasts. ${ }^{3-5}$

Depending on the external cues present in inflammatory microenvironment, the macrophages can assume different phenotypes in a spectrum between the extremes of the classically activated or pro-inflammatory (M1), and alternatively activated or reparative (M2) macrophages, according to the major cytokines secreted. The characterization of macrophage response and phenotype associated with inflammatory conditions, including periodontal diseases, may be useful in developing new treatment strategies. ${ }^{6}$

There has been a growing interest in natural products with antimicrobial and anti-inflammatory properties as adjunct treatments for many infectious and inflammatory conditions, including periodontitis. ${ }^{7-9}$ These products include essential oils, which are volatile aromatic liquids extracted from plants and are active ingredients of phytotherapy. ${ }^{9}$ Monoterpenes are the main constituents of essential oils, and most studies of their effects on human health have been performed with limonene, carvone, camphor, and perillyl alcohol $(\mathrm{POH})$. The $\mathrm{POH}$ can be found in several essential oils, ${ }^{10-12}$ and medical interest in this compound was initially based on its anti-tumoral activity. ${ }^{13-17}$

Recent studies have shown immunomodulatory properties of the $\mathrm{POH}$, which may be of interest in the treatment of non-neoplastic inflammatory disorders. D'Alessio, et al. ${ }^{18}$ (2014) reported that the $\mathrm{POH}$ promotes wound healing, likely by decreasing the pro-inflammatory cytokines IL- 6 and TNF. The POH reduced oxidative activity, TNF production, and NF$\mathrm{kB}$ activation in a rat model of ethanol-induced acute hepatic injury. ${ }^{19}$ In addition, the antinociceptive activity of the $\mathrm{POH}$ has recently been shown in a murine model of orofacial pain. ${ }^{20}$

Despite evidence of the immunomodulatory potential of the $\mathrm{POH}$, few studies have assessed the biological mechanisms of the $\mathrm{POH}$ on cells directly involved in the pathogenesis of inflammatory disorders, including periodontitis. Considering the fundamental roles of the Gram-negative microorganisms and of the macrophages in the etiopathogenesis of periodontal diseases, this study determines the antimicrobial activity and the $\mathrm{POH}$ effects in the macrophage response.

\section{Methodology}

\section{Determination of antimicrobial activity against periodontal pathogens}

The antimicrobial susceptibility test was performed according to the broth macrodilution method, M11-A5, of the CLSI (Clinical and Laboratory Standards Institute) with some modifications. ${ }^{21}$ The bacterial inoculum was prepared by the suspension of colonies of Fusobacterium nucleatum (ATCC 25586, Manassas, VA, USA) and Porphyromonas gingivalis (ATCC 33277, Manassas, VA, USA) in $5 \mathrm{~mL}$ of brain heart infusion $(\mathrm{BHI})$ broth supplemented with hemin $(5 \mu \mathrm{g} / \mathrm{mL})$ and menadione ( $1 \mu \mathrm{g} / \mathrm{mL}$ of vitamin $\mathrm{K}$ ), followed by incubation under anaerobic conditions $\left(90 \% \mathrm{~N}_{2}\right.$ and $10 \% \mathrm{CO}_{2}$ ) at $37^{\circ} \mathrm{C}$ for $48 \mathrm{~h}$. Then, the inoculum was adjusted to $1.5 \times 10^{8}$ colony forming units (CFU)/mL. The $\mathrm{POH}$ stock solution $(50 \mathrm{mg} / \mathrm{mL})$ was prepared using $4 \%$ dimethyl sulfoxide as the solvent (DMSO, Sigma-Aldrich, St. Louis, MO, USA). Increasing $\mathrm{POH}$ concentrations $(0.00781-1 \mathrm{mg} / \mathrm{mL})$ were used for testing, and $0.12 \%$ chlorhexidine gluconate (Periogard ${ }^{\circledR}$; Colgate-Palmolive Ind. Bras., Osasco, SP, Brazil) was used as a positive control. The minimum inhibitory concentration (MIC) was determined by observing the mean turbidity and/or presence of sediment. To determine the minimum bactericidal concentration $(\mathrm{MBC}), 10 \mu \mathrm{L}$ aliquots from the test 
tubes without visible growth were plated on blood agar supplemented with hemin $(5 \mu \mathrm{g} / \mathrm{mL})$ and menadione $(1 \mu \mathrm{g} / \mathrm{mL}$ of vitamin $\mathrm{K})$, and then incubated under anaerobic conditions $\left(90 \% \mathrm{~N}_{2}\right.$ and $\left.10 \% \mathrm{CO}_{2}\right)$ at $37^{\circ} \mathrm{C}$ for $72 \mathrm{~h}$. Three independent experiments assessed in triplicate were performed.

\section{Cell line and preparation of perillyl alcohol}

The commercially available RAW 264.7 murine macrophage cell line (ATCC \#TIB-71) was used in this study. This cell line has been widely used in the literature and is responsive to LPS, PMA, and polarization induced by LPS and IFN-Y (M1) or IL-4 (M2). .2-24 $^{2}$

The cells were cultured in Dulbecco's Modified Eagle Medium (DMEM) supplemented with 10\% heat inactivated fetal bovine serum (FBS), $100 \mathrm{U} /$ $\mathrm{mL}$ penicillin, and $100 \mu \mathrm{g} / \mathrm{mL}$ streptomycin and then maintained in a humidified atmosphere at $37^{\circ} \mathrm{C}$ containing $5 \% \mathrm{CO}_{2}$. The (S)-(-)-perillyl alcohol, 96\%, was obtained from Sigma Aldrich Chemical Co (St. Louis, MO, USA). A stock solution (25 mM) was prepared in FBS and diluted in DMEM at the final concentrations of $10 \mu \mathrm{M}, 25 \mu \mathrm{M}, 50 \mu \mathrm{M}, 100 \mu \mathrm{M}$, and $250 \mu \mathrm{M}$ for the experiments.

\section{Cytotoxicity assays: trypan blue and MTS assay}

Cytotoxicity was assessed by the trypan blue dye exclusion test and by the mitochondrial enzymatic activity (MTS) assay (3-[4,5, dimethylthiazol-2-yl]5-[3-carboxymethoxy-phenyl]-2-[4-sulfophenyl]$2 \mathrm{H}$-tetrazolium). The RAW 264.7 cells were plated in 96-well plates at densities of $1 \times 10^{5}$ and $5 \times 10^{4}$ cells/well for the trypan blue test and MTS assay, respectively, and stimulated with $\mathrm{POH}$ at concentrations of $10 \mu \mathrm{M}$, $25 \mu \mathrm{M}, 50 \mu \mathrm{M}, 100 \mu \mathrm{M}$, and $250 \mu \mathrm{M}$ for $24 \mathrm{~h}$. The negative control consisted of non-stimulated cells, and the positive control consisted of cells treated with 6 $\mu \mathrm{M}$ camptothecin (Sigma-Aldrich Co, St. Louis, MO, USA). After the experimental period, the cells were resuspended at a ratio of $1: 1$ with $0.4 \%$ trypan blue (Gibco, Thermo Fisher Scientific, Waltham, MA, USA) and counted in a hemocytometer after 2 minutes of incubation. The results were expressed as percentage of viable cells regarding the total number of cells.

The MTS assay determines the number of viable cells using the activity of mitochondrial dehydrogenases that convert tetrazolium salts to formazan, generating a colorimetric reaction. . 5,26 The MTS assay was conducted according to the manufacturer's instructions (CellTiter
96 ${ }^{\circledR}$ AQueous One Solution Cell Proliferation Assay, Promega, Madison, WI, USA). The absorbance was measured at $490 \mathrm{~nm}$ in a plate reader (Spectramax L, Molecular Devices, Sunnyvale, CA), and the enzyme activity in the treatment groups was estimated as a percentage regarding the respective negative controls.

\section{Cell proliferation assay}

The RAW 264.7 cells were plated in 96-well plates at a density of $1 \times 10^{4}$ cells/well and stimulated with $\mathrm{POH}$ at concentrations of $10 \mu \mathrm{M}, 25 \mu \mathrm{M}, 50 \mu \mathrm{M}, 100$ $\mu \mathrm{M}$, and $250 \mu \mathrm{M}$ for periods of 24,48 , and $72 \mathrm{~h}$. The negative control consisted of the non-stimulated cells, and $10 \mu \mathrm{g} / \mathrm{mL}$ mitomycin was used as the positive control (Sigma-Aldrich Co, St. Louis, MO, USA). At each experimental period, the cells in suspension in the culture medium and the attached cells (removed by a 5 -minute incubation in $0.25 \%$ trypsin) were resuspended at a $1: 1$ ratio with $0.4 \%$ trypan blue, then incubated for 2 minutes at room temperature, and the number of viable (unstained) and dead (blue) cells were estimated in a hemocytometer by a trained examiner. The results were expressed as the absolute number of live cells.

\section{Production of reactive oxygen species (ROS)}

The $\mathrm{POH}$ effect on ROS production was assessed by flow cytometry. Macrophages were seeded in 6-well plates ( $3 \times 10^{5}$ cells per well). After $24 \mathrm{~h}$ of incubation, the culture medium was removed, the cells were gently washed with phosphate buffered saline (PBS) twice ( $\mathrm{pH} 7.4$, without $\mathrm{Ca}$ and $\mathrm{Mg}$ ), and PBS containing $10 \mu \mathrm{M}$ 6-carboxy-2',7'-dichlorodihydrofluorescein diacetate (cat\# C400, Molecular Probes, Thermo Fisher Scientific, Waltham, MA, USA). The cells were loaded with this compound (a molecular ROS sensor) by incubation at $37^{\circ} \mathrm{C}$ for 30 minutes. After the removal of the reagent and washing the cells with PBS, the $\mathrm{POH}$ was added at $10 \mu \mathrm{M}$ and $100 \mu \mathrm{M}$ in complete culture medium. After 30 minutes, the cells were stimulated with $50 \mathrm{ng} / \mathrm{mL}$ phorbol myristate acetate (PMA) (cat\# P1585, Sigma-Aldrich Co, St. Louis, MO, USA) and 10 $\mu \mathrm{g} / \mathrm{mL}$ LPS (E. coli, serotype 0111:B4, cat\# L4130, Sigma-Aldrich Co, St. Louis, MO, USA) for 20 minutes to induce ROS production. The cells were harvested by trypsinization, resuspended in PBS containing $2 \%$ FBS, and analyzed by flow cytometry (BD FacsVerse, BD Biosciences, San Jose, CA, USA). A minimum of 10,000 events were acquired and the percentage of positive events in the FL1 (FITC) channel (ROS- 
producing cells) was recorded. Three independent experiments were performed. Data are expressed as the percentage of cells emitting fluorescence in the FL1 channel (ROS-positive cells).

\section{TNF and arginase gene expression}

The $\mathrm{POH}$ effect on expression of M1/M2-related genes was determined by analyzing TNF (M1) and Arginase-1 (M2) by reverse transcriptase real-time PCR (RT-qPCR). Macrophages were plated in 6-well plates ( $3 \times 10^{5}$ cells/well). After a $4 \mathrm{~h}$ incubation to allow cell adhesion, the plates were treated with $\mathrm{POH}$ at 10 $\mu \mathrm{M}$ and $100 \mu \mathrm{M}$ for $24 \mathrm{~h}$. After $24 \mathrm{~h}$, the macrophages were stimulated with LPS $(1 \mu \mathrm{g} / \mathrm{mL}$, Sigma Aldrich Co, St. Louis, MO, USA) and recombinant murine IFN-Y (100 ng/mL, cat\# 315-05, Peprotech Inc, Rocky Hill, NJ, USA) as the M1-polarizing conditions, or with recombinant murine $\mathrm{IL}-4(40 \mathrm{ng} / \mathrm{mL}$, cat\# 214-14, Peprotech Inc, Rocky Hill, NJ, USA) as the $\mathrm{M} 2$-polarizing condition. After an additional $24 \mathrm{~h}$, the adhered cells were collected, and the total RNA was isolated using an affinity column system including treatment with DNAse (Total RNA Purification Kit, cat\# DPK-108, Cellco Biotec, São Carlos, SP, Brazil). The concentration and purity of the RNA were determined in a UV spectrophotometer, and 300 ng of total RNA was used for synthesis of complementary DNA (cDNA) using random hexameters as primers and recombinant transcriptase, according to the instructions of the supplier of the reagents (High capacity cDNA reverse transcription, cat\# 4368814, Applied Biosystems, Thermo Fisher Scientific, Waltham, MA, USA). The CDNA was used in qPCR reactions using the TaqMan chemistry (TaqMan Fast Advanced, cat\# 4444556, Applied Biosystems, Thermo Fisher Scientific, Waltham, MA, USA) and the pre-designed and optimized sets of primers and probe for each gene of interest (TaqMan gene expression assays, cat\# 4331182, Applied Biosystems, Thermo Fisher Scientific, Waltham, MA, USA) on a StepOne Plus qPCR thermocycler (Applied Biosystems, Thermo Fisher Scientific, Waltham, MA, USA). The GAPDH was used as the internal control, and relative gene expression was determined using the $\Delta(\Delta \mathrm{Ct})$ method.

\section{Statistical analysis}

Before the analysis, the data normality was verified with the Shapiro-Wilk test. For comparisons between the experimental groups, the ANOVA followed by the Tukey's post hoc test were used. Data are expressed as the mean \pm standard deviation, and the analysis were performed in the GraphPad version 7.0 with the significance level set at 95\% $(p<0.05)$.

\section{Results}

\section{Antimicrobial activity of the $\mathrm{POH}$ against periodontal pathogens}

The $\mathrm{POH}$ had an antimicrobial activity against $P$. gingivalis and $F$. nucleatum at the same concentration (MIC $1600 \mu M)$, and the MBC was equal to the MIC for both microorganisms (Table 1 ).

\section{Cytotoxicity and cell proliferation assays}

The RAW 264.7 cells were treated with the indicated concentrations of $\mathrm{POH}(10-250 \mu \mathrm{M})$ for $24 \mathrm{~h}$. Cell viability was not significantly affected by up to 250 $\mu \mathrm{M}$ of $\mathrm{POH}$, as determined by the trypan blue exclusion test (over $85 \%$ viable cells in all concentrations, Figure $1 \mathrm{~A}$ ). The camptothecin (positive control) significantly reduced viability (54\% viable cells). The MTS indicated significant cytotoxicity of $\mathrm{POH}$ at $250 \mu \mathrm{M}$ (Figure 1B).

The $\mathrm{POH}$ effect $(10-250 \mu \mathrm{M})$ on proliferation was determined by direct cell counting at 24, 48, and $72 \mathrm{~h}$. The $\mathrm{POH}$ at $10-250 \mu \mathrm{M}$ significantly inhibited proliferation of macrophages only at $72 \mathrm{~h}$; however, the $\mathrm{POH}$ at $100 \mu \mathrm{M}$ significantly reduced the total number of cells from $48 \mathrm{~h}$ (Figure 1C). Two noncytotoxic concentrations of $\mathrm{POH}(10$ and $100 \mu \mathrm{M})$, as determined in these proliferation and cytotoxicity assays, were used in the subsequent experiments.

\section{ROS production}

The $\mathrm{POH}$ alone at $100 \mu \mathrm{M}$ caused a statistically significant increase in the ROS production when

Table 1- Minimum inhibitory concentration (MIC) and minimum bactericidal concentration (MBC) given in $\mu \mathrm{g} / \mathrm{mL}$ for $\mathrm{POH}$ and chlorhexidine at $0.12 \%$ (control) against strict anaerobes

\begin{tabular}{ccccc}
\hline & \multicolumn{1}{c}{$\boldsymbol{P .}$ gingivalis } & F. nucleatum \\
\hline Substances & $\mathrm{MIC}(\mu \mathrm{M})$ & $\mathrm{MBC}(\mu \mathrm{M})$ & $\mathrm{MIC}(\mu \mathrm{M})$ & 1600 \\
$\mathrm{POH}$ & 1600 & 1600 & $\mathrm{MBC}(\mu \mathrm{M})$ & 1600 \\
Chlorhexidine & 0.0000037 & 0.0000037 & 0.00000742 & 0.00000742 \\
\hline
\end{tabular}



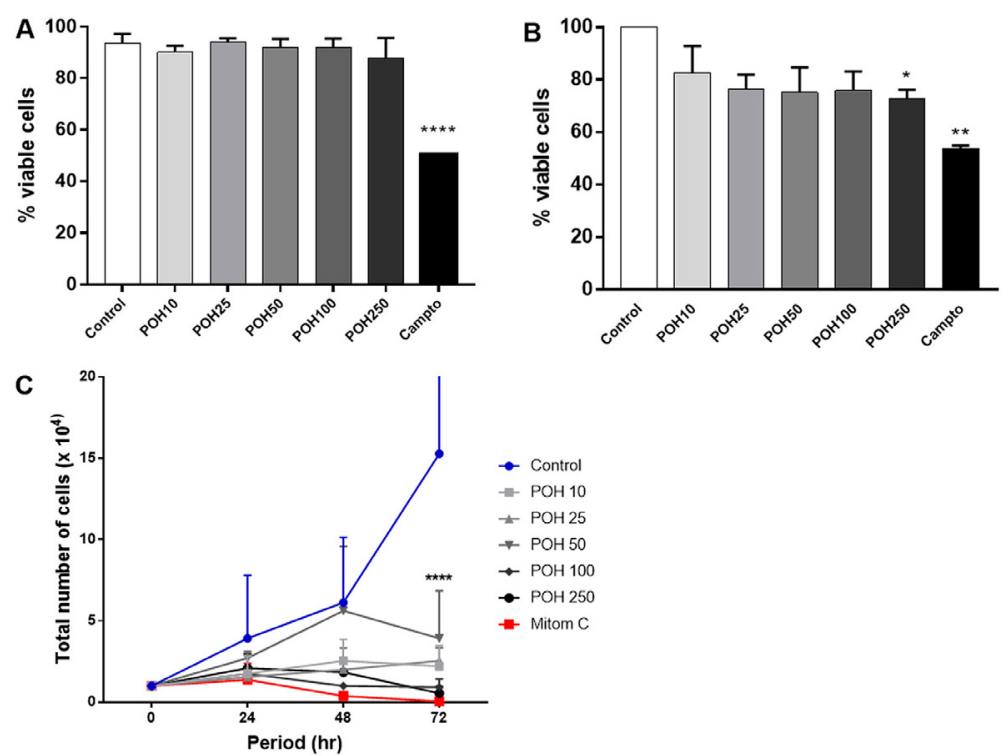

Figure 1- $\mathrm{POH}$ effect on macrophage viability and proliferation. The RAW 264.7 cells were treated with $\mathrm{POH}(10-250 \mu \mathrm{M})$ and cultured in vitro for 24,48 , or $72 \mathrm{~h}$. The viability was determined by the trypan blue (A) and MTS (B) assays at $24 \mathrm{~h}$. The bars represent the means, and the vertical lines represent the standard deviations of three independent experiments. C): POH effect on proliferation of RAW 264.7 cells at 24, 48, and $72 \mathrm{~h}$. Each horizontal line represents an experimental condition, and the vertical lines represent the standard deviations of three independent experiments. The asterisks $\left.{ }^{(* * *}\right)$ indicates a significant difference compared to the negative control (2-way ANOVA, $p<0.0001)$


Figure 2- POH effect on ROS production induced by PMA (A) and LPS (B) in RAW 264.7 macrophages. The cells were treated with 10 $\mu \mathrm{M}$ and $100 \mu \mathrm{M}$ of POH for 30 minutes, followed by a 20 -minute stimulation with $50 \mathrm{ng} / \mathrm{mL}$ PMA or $10 \mu \mathrm{g} / \mathrm{mL}$ LPS. The ROS production was assessed by flow cytometry by measuring the oxidation of the substrate 6-carboxy-2',7'-dichlorodihydrofluorescein diacetate, which emits fluorescence in the green channel (FITC) upon excitation at $488 \mathrm{~nm}$. Representative dot-plots of flow cytometry analysis depicting the percentage of ROS-positive (FITC-positive) cells. Significant differences are based on the ANOVA with a post-hoc Tukey test. ${ }^{*} p<0.05$, ${ }^{* *} p<0.01,{ }^{* * *} p<0.001$ versus control or as indicated in the figure 

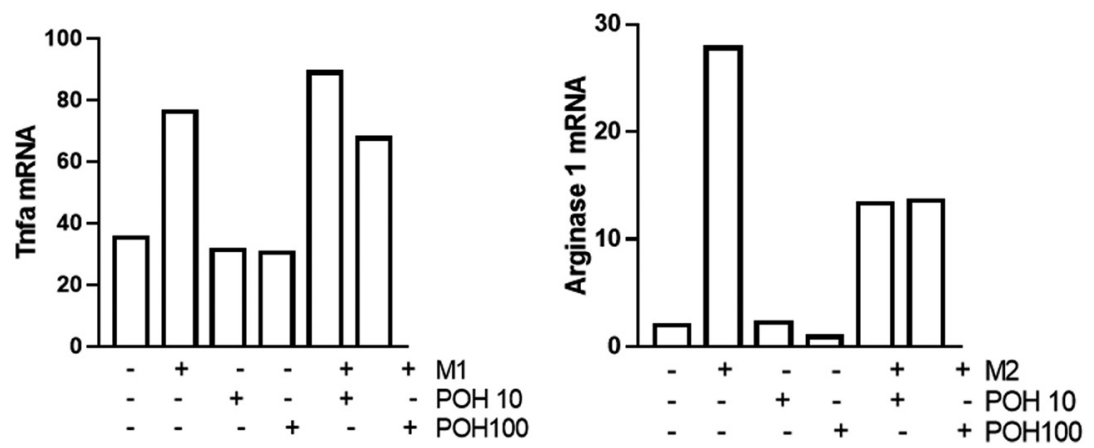

Figure 3- Expression of TNF and Arginase-1 assessed by the RT-qPCR in RAW 264.7 cells. M1 stimuli were E. coli LPS (1 $\mu \mathrm{g} / \mathrm{mL})$ and IFNy $(100 \mathrm{ng} / \mathrm{mL})$ in pre-treated cells $(30 \mathrm{~min})$ with $10 \mu \mathrm{M}$ or $100 \mu \mathrm{M}$ of POH (control cells were treated with the same vehicle of the vehicle used to dilute $\mathrm{POH}$ ). Columns represent the means for two independent experiments

compared to the control group ( $p$ value $<0.01$ ) However, it did not affect the PMA-induced production of ROS at either concentration (10 $\mu \mathrm{M}$ and $100 \mu \mathrm{M})$ (Figure 2A). Conversely, the $\mathrm{POH}$ had a concentrationdependent effect on the LPS-induced ROS production. At $10 \mu \mathrm{M}$, the $\mathrm{POH}$ had a significant $(\mathrm{p}<0.01)$ synergistic effect with the LPS on ROS induction, whereas at $100 \mu \mathrm{M}$ there was a significant reduction in the LPS-induced ROS production $(p<0.05)$ (Figure $2 B$ ).

\section{Gene expression of TNF and Arginase 1}

The $\mathrm{POH}$ alone $(10 \mu \mathrm{M}$ and $100 \mu \mathrm{M})$ did not affect expression of TNF or Arginase-1 by macrophages. The TNF was increased by stimulation with LPS and IFN-gamma, and pre-treatment with $\mathrm{POH}$ (10 and 100 $\mu \mathrm{M})$ had no effect. The $\mathrm{POH}$ partially inhibited IL-4induced expression of Arginase-1 POH at both 10 and $100 \mu \mathrm{M}$ (Figure 3).

\section{Discussion}

$\mathrm{POH}$ is a natural monoterpene found in several essential oils, and its antitumor activity has been well established in the literature and supported by in vitro and in vivo studies, and Phase II clinical trials in cancer patients. ${ }^{10-12,15,27,28}$ Recent studies have suggested that the $\mathrm{POH}$ also plays a role in the immunoinflammatory response. ${ }^{18,19}$

Periodontitis is a chronic inflammatory condition associated with a dysbiotic microbial biofilm that may benefit from immuno-regulatory properties of the $\mathrm{POH}$. The researchers of this study did not find any studies on the antibacterial activity of the $\mathrm{POH}$ against periodontal pathogens. The $\mathrm{POH}$ had MIC and MBC values of $1600 \mu \mathrm{M}(250 \mu \mathrm{g} / \mathrm{mL})$ for two prominent Gram-negative microorganisms associated with periodontal disease: $P$. gingivalis and $F$. nucleatum, with bactericidal action. Natural products with MIC values between 101 and $500 \mu \mathrm{g} / \mathrm{mL}$ are considered strong inhibitors of microbial activity. ${ }^{29}$ These results will be expanded to include other Gram-negative species associated with periodontal diseases, such as Aggregatibacter actinomycetemcomitans. Another data limitation of the study is the assessment of the antibacterial activity in the planktonic form as opposed to the biofilm assays.

$\mathrm{POH}$ was not cytotoxic to human peripheral blood mononuclear cells (PBMCs) at 0.625-5 mM. ${ }^{30}$ Specifically in RAW264.7 cells, the reported $\mathrm{IC}_{50}$ of $\mathrm{POH}$ diluted in $10 \%$ DMSO was above $50 \mu \mathrm{M} .{ }^{31}$ Agreeing with these data, this study showed that the $\mathrm{POH}$ was not cytotoxic to RAW264.7 cells up to a concentration of $100 \mu \mathrm{M}$. All subsequent experiments used noncytotoxic concentrations of $\mathrm{POH}$ to avoid possible bias.

The literature reports contrasting $\mathrm{POH}$ effects on cell proliferation. Different experimental conditions, such as $\mathrm{POH}$ concentrations and cell types may account for the discrepancies. Toro-Arreola, et al. ${ }^{32}$ (2005) observed that $0.025 \mu \mathrm{M} \mathrm{POH}$ was a weak inducer of proliferation of murine lymphocytes, whereas higher $\mathrm{POH}$ concentrations inhibited proliferation. In human peripheral blood lymphocytes, the $\mathrm{POH}$ had a concentration-dependent (0.625-5 mM) inhibitory effect on proliferation. ${ }^{30}$ The $\mathrm{POH}$ significantly reduced proliferation of murine macrophages in vitro starting at $48 \mathrm{~h}$ of treatment $(100 \mu \mathrm{M})$, with a more pronounced effect at $72 \mathrm{~h}(100 \mu \mathrm{M}$ and $250 \mu \mathrm{M})$.

ROS production is a major biological process in stimulated macrophages involved in the killing of phagocytized microorganisms and in the production of other soluble inflammatory mediators. ${ }^{33}$ The $\mathrm{POH}$ has been shown to have both pro- and antioxidant effects, especially in tumor cells. ${ }^{34,35}$ However, there are no studies assessing the $\mathrm{POH}$ effect on 
the ROS production to compare with macrophages. In this study, the $\mathrm{POH}$ alone at $100 \mu \mathrm{M}$ induced a statistically significant increase in the ROS production and did not affect ROS production induced by PMA. Interestingly, the $\mathrm{POH}$ effect on the LPS-induced ROS was concentration-dependent: $10 \mu \mathrm{M}$ further increased and $100 \mu \mathrm{M}$ reduced LPS-induced ROS. This suggests that the $\mathrm{POH}$ modulates ROS production induced via activation of TLR $4,{ }^{36}$ but not via the protein kinase $\mathrm{Ca}$ (PKCa) pathway activated by PMA. ${ }^{37}$

An important characteristic of macrophages is their phenotypic plasticity in response to the microenvironmental cues. This study assessed the expression of TNF and Arginase-1 as genes representative of the $\mathrm{M} 1 /$ pro-inflammatory and $\mathrm{M} 2$ / reparative phenotypes, respectively. The $\mathrm{POH}$ alone had no effect on the expression of TNF or Arginase-1. Moreover, the TNF expression induced by M1-polarizing stimuli was also not affected by $\mathrm{POH}$. Interestingly, the $\mathrm{POH}$ at 10 and $100 \mu \mathrm{M}$ reduced the expression of Arginase- 1 induced by M2-polarizing stimulus. These results suggest that $\mathrm{POH}$ may favor the $\mathrm{M} 1$ phenotype, although it is important to note the limitation of assessing gene expression and not protein production.

Macrophage polarization is a complex process finely controlled by intracellular signaling pathways activated by the external stimuli. The M1-inducing stimuli used in this study activates predominantly STAT1 (IFNY) and MAPKs and NF-kB. ${ }^{38}$ The IL-4 used as an M2-polarizing stimulus activates primarily STAT6. ${ }^{39}$ The reduction of IL-4-induced Arginase- 1 by $\mathrm{POH}$ suggests an inhibition of STAT6, as inhibition of STAT6 by siRNA or the biochemical inhibitor AS1517499 inhibits expression of Arginase- 1 and Arginase activity induced by IL-4 and IL-13 in RAW264.7 cells. ${ }^{40}$ It is intriguing that the $\mathrm{POH}$ modulates the TLR-induced ROS, which also involves MAPK and NF-kB as major downstream signaling pathways, but not the TNF expression. These possibilities should be assessed in future experiments, which should also assess the $\mathrm{POH}$ effect on periodontitis and the associated inflammation in vivo.

\section{Conclusion}

$\mathrm{POH}$ has a strong antibacterial effect against $P$. gingivalis. and F. nucleatum. Up to $100 \mu \mathrm{M}$, the $\mathrm{POH}$ was not cytotoxic to murine macrophages, but reduced proliferation, LPS-induced ROS production, and IL-4induced expression of Arginase-1.

\section{Acknowledgements}

This study was funded by the Coordination of Higher Education and Graduate Training (CAPES) of the Brazilian Government.

\section{Conflict of Interest}

The authors declare no conflict of interest.

\section{Authors' Contributions}

Figueiredo, Rebeca Dantas Alves: Data curation (Equal); Investigation (Equal); Writing, original draft (Equal); Cabrera Ortega, Adriana Alicia: Data curation (Equal); González-Maldonado, Laura Andrea: Data curation (Equal); Castro, Ricardo Dias de: Conceptualization (Equal); Writing, review, and editing (Equal); Avila-Campos, Mario J.: Data curation (Equal); Rossa Junior, Carlos: Conceptualization (Equal); Formal analysis (Equal); Resources (Equal); Writing, review, and editing (Equal); Aquino, Sabrina Garcia: Conceptualization (Equal); Formal analysis (Equal); Project administration (Equal); Writing, review, and editing (Equal).

\section{References}

1- Dentino A, Lee S, Mailhot J, Hefti AF. Principles of periodontology. Periodontol 2000. 2013;61(1):16-53. doi: 10.1111/j.16000757.2011.00397.x

2- Hassel TM. Tissues and cells of the periodontium. Periodontol 2000. 1993;3(1):9-38. doi: 10.1111/j.1600-0757.1993.tb00230.x 3- Holden JA, Attard TJ, Laughton KM, Mansell A, O'Brien-Simpson NM, Reynolds EC. Porphyromonas gingivalis lipopolysaccharide weakly activates M1 and M2 polarized mouse macrophages but induces inflammatory cytokines. Infect Immun. 2014;82(10):4190-203. doi: 10.1128/IAI.02325-14

4- Lam RS, O'Brien-Simpson NM, Holden JA, Lenzo JC, Fong SB, Reynolds EC. Unprimed, M1 and M2 macrophages differentially interact with Porphyromonas gingivalis. PLoS ONE. 2016;11(7):1-17. doi: 10.1371/journal.pone. 0158629

5- Kwan Tat S, Padrines M, Théoleyre S, Heymann D, Fortun Y. IL-6, RANKL, TNF-alpha/IL-1: interrelations in bone resorption pathophysiology. Cytokine Growth Factor Rev. 2004;15(1):49-60. doi: 10.1016/j.cytogfr.2003.10.005

6- Chávez-Galán L, Olleros ML, Vesin D, Garcia I. Much more than M1 and M2 macrophages, there are also CD169(+) and TCR(+) macrophages. Front Immunol. 2015;6:1-15. doi: 10.3389/ fimmu.2015.00263

7- Guimarães MR, Coimbra LS, Aquino SG, Spolidorio LC, Kirkwood KL, Rossa C Jr. Potent anti-inflammatory effects of systemically administered curcumin modulate periodontal disease in vivo. J Periodontal Res. 2011;46(2):269-79. doi: 10.1111/j.1600-0765.2010.01342.x 
8- Jayash SN, Hashim NM, Misran M, Baharuddin NA. In vitro evaluation of osteoprotegerin in chitosan for potential bone defect applications. Peer]. 2016;4:e2229. doi: 10.7717/peerj. 2229

9- Shojaei S, Kiumarsi A, Moghadam AR, Alizadeh J, Marzban H, Ghavami S. Perillyl alcohol (monoterpene alcohol), limonene. Enzymes. 2014;36(7):7-32. doi: 10.1016/B978-0-12-802215-3.00002-1 10- Belanger JT. Perillyl alcohol: applications in oncology. Altern Med Rev. 1998;3(6):448-57.

11- Kelloff GJ, Boone CW, Crowell JA, Steele VE, Lubet RA, Doody LA, et al. New agents for cancer chemoprevention. J Cell Biochem. 1996;26:1-28. doi: 10.1002/jcb.240630703

12- Tyler VE, Brady LR, Robbers JE. Pharmacognosy. $9^{\text {th }}$ ed. Philadelphia: Lea \& Febiger; 1988.

13- Chen TC, Fonseca CO, Schönthal AH. Preclinical development and clinical use of perillyl alcohol for chemoprevention and cancer therapy. Am J Cancer Res. 2015;5(5):1580-93.

14- Elegbede JA, Flores R, Wang RC. Perillyl alcohol and perillaldehyde induced cell cycle arrest and cell death in BroTo and A549 cells cultured in vitro. Life Sci. 2003;73(22):2831-40. doi: 10.1016/s00243205(03)00701-x

15- Gómez-Contreras PC, Hernández-Flores G, Ortiz-Lazareno PC Toro-Arreola S, Delgado-Rizo V, Lerma-Díaz, et al. In vitro induction of apoptosis in U937 cells by perillyl alcohol with sensitization by pentoxifylline: increased BCL-2 and BAX protein expression. Chemotherapy. 2016;52(6):308-15. doi: 10.1159/000096003 16- Grassmann J. Terpenoids as plant antioxidants. Vitam Horm. 2005;72:505-35. doi: 10.1016/S0083-6729(05)72015-X

17- Stayrook KR, McKinzie JH, Burke YA, Crowell PL. Induction of the apoptosis-promoting protein Bak by perillyl alcohol in pancreatic ductal adenocarcinoma relative to untransformed ductal epitelial cells. Carcinogenesis. 1997;18(8):1655-8. doi: 10.1093/carcin/18.8.1655 18- D'Alessio PA, Mirshahi M, Bisson JF, Bene MC. Skin repair properties of $d$-Limonene and perillyl alcohol in murine models. AntiInflamm Antiallergy Agents Med Chem. 2014;13(1):29-35. doi: 10.2174/18715230113126660021

19- Khan AQ, Nafees S, Sultana S. Perillyl alcohol protects against ethanol induced acute liver injury in Wistar rats by inhibiting oxidative stress, NFk-B activation and proinflammatory cytokine production. Toxicology. 2011;279:108-14. doi: 10.1016/j.tox.2010.09.017

20- Tomaz-Morais JF, Braga RM, Sousa FB, Sousa DP, Pordeus LC, Almeida RN, et al. Orofacial antinociceptive activity of (S)-(-)perillyl alcohol in mice: a randomized, controlled and triple-blind study. Int J Oral Maxillofac Surg. 2017;46(5):662-7. doi: 10.1016/j. ijom.2017.01.024

21- Clinical and Laboratory Standards Institute - CLSI. M11-A5: Methods for antimicrobial susceptibility testing of anaerobic bacteria. 7th edition. Clinical and Laboratory Standards Institute, Wayne: Clinical and Laboratory Standards Institute: 2007.

22- Matsebatlela TM, Anderson AL, Gallicchio VS, Elford H, Rice CD. 3,4-Dihydroxy-benzohydroxamic acid (Didox) suppresses proinflammatory profiles and oxidative stress in TLR4-activated RAW264.7 murine macrophages. Chem Biol Interact. 2015;233:95-105. doi: 10.1016/j.cbi.2015.03.027

23- Woo $\mathrm{CH}$, Lim JH, Kim JH. Lipopolysaccharide induces matrix metalloproteinase- 9 expression via a mitochondrial reactive oxygen species-p38 kinase-activator protein-1 pathway in Raw 264.7 cells. J Immunol. 2004;173(11):6973-80. doi: 10.4049/jimmunol.173.11.6973 24- Yuan X, Cao H, Wang J, Tang K, Li B, Zhao Y, et al. Immunomodulatory effects of calcium and strontium co-doped titanium oxides on osteogenesis. Front Immunol. 2017;8:1196. doi: 10.3389/ fimmu. 2017.01196
25- Berridge MV, Tan AS. Characterization of the cellular reduction of 3-(4,5-dimethylthiazol-2-yl)-2,5-diphenyltetrazolium bromide (MTT): subcellular localization, substrate dependence, and involvement of mitochondrial electron transport in MTT reduction. Arch Biochem Biophys. 1993;303(2):474-82. doi: 10.1006/abbi.1993.1311

26- Cory AH, Owen TC, Barltrop JA, Cory JG. Use of an aqueous soluble tetrazolium/formazan assay for cell growth assays in culture. Cancer Commun. 1991;3(7):207-12. doi: 10.3727/095535491820873191 27- Bailey HH, Attia S, Love RR, Fass T, Chappell R., Tutsch K, et al. Phase II trial of daily oral perillyl alcohol (NSC 641066) in treatmentrefractory metastatic breast cancer. Cancer Chemother Pharmacol. 2008;62(1):149-57. 10.1007/s00280-007-0585-6

28- Chaudhary SC, Alam MS, Siddiqui MS, Athar M. Perillyl alcohol attenuates Ras-ERK signaling to inhibit murine skin inflammation and tumorigenesis. Chem Biol Interact. 2009;179(2-3):145-53. doi: 10.1016/j.cbi.2008.12.016

29- Freires IA, Denny C, Benso B, Alencar SM, Rosalen PL. Antibacterial activity of essential oils and their isolated constituents against cariogenic bacteria: a systematic review. Molecules. 2015;20(4):732959. doi: 10.3390/molecules20047329

30- Schulz S, Bühling F, Ansorge S. Prenylated proteins and lymphocyte proliferation: inhibition by d-limonene and related monoterpenes. Eur J Immunol. 1994;24(2):301-7. doi: 10.1002/eji.1830240204

31- Gerhäuser G, Klimo K, Heiss E, Neumann I, Gamal-Eldeen A, Knauft J, et al. Mechanism-based in vitro screening of potential cancer chemopreventive agents. Mutat Res. 2003;523-524:163-72. doi: 10.1016/s0027-5107(02)00332-9

32- Del Toro-Arreola S, Flores-Torales E, Torres-Lozano C, Del Toro-Areola A, Tostado-Pelayo K, Ramirez-Dueñas MG, et al. Effect of $D$-limonene on imune response in BALB/c mice with lymphoma. Int Immunopharmacol. 2005;5(5):829-38. doi: 10.1016/j. intimp.2004.12.012

33- Dupré-Crochet $S$, Erard M, Nüße O. ROS production in phagocytes: why, when, and where? J Leukoc Biol. 2013;94(4):657-70. doi: 10.1189/jlb.1012544

34- Gomes AC, Mello AL, Ribeiro MG, Garcia DG, Fonseca CO, Salaza $M D$, et al. Perillyl alcohol, a pleiotropic natural compound suitable for brain tumor therapy, targets free radicals. Arch Immunol Ther Exp. 2017;65(4):285-97. doi: 10.1007/s00005-017-0459-5

35- Xu Y, Wang W, Jin K, Zhu Q, Lin H, Xie M, et al. Perillyl alcohol protects human renal tubular epithelial cells from hypoxia/ reoxygenation injury via inhibition of ROS, endoplasmic reticulum stress and activation of PI3K/Akt/eNOS pathway. Biomed Pharmacother. 2017;95:662-9. doi: 10.1016/j.biopha.2017.08.129

36- Takeda K, Kaisho T, Akira S. Toll-like receptors. Annu Rev Immunol. 2003;21:335-76. doi: 10.1146/annurev.immunol.21.120601.141126 37- Kohl R, Preiss S, von Knethen A, Brüne B. Oxidized low-density lipoprotein depletes PKCalpha and attenuates reactive oxygen species formation in monocytes/macrophages. Cardiovasc Res. 2006;71(3):574-85. doi: 10.1016/j.cardiores.2006.05.023

38- Wang $\mathrm{N}$, Liang $\mathrm{H}$, Zen $\mathrm{K}$. Molecular mechanisms that influence the macrophage m1-m2 polarization balance. Front Immunol. 2014;5:614. doi: 10.3389/fimmu.2014.00614

39- Han MS, Jung DY, Morel C, Lakhani SA, Kim JK, Flavell RA, et al. JNK expression by macrophages promotes obesity-induced insulin resistance and inflammation. Science. 2013;339(6116):218-22. doi: 10.1126/science. 1227568

40- Binnemars-Postma K, Bansal R, Storm G, Prakash J. Targeting the Stat6 pathway in tumor-associated macrophages reduces tumor growth and metastatic niche formation in breast cancer. FASEB J. 2018;32(2):969-78. doi: 10.1096/fj.201700629R 